\title{
Dysregulated A to I RNA editing and non-coding RNAs in neurodegeneration
}

\author{
Minati Singh* \\ Department of Internal Medicine, University of lowa, lowa City, IA, USA
}

Edited by:

Peng Jin, Emory University School of

Medicine, USA

Reviewed by:

Sebastien S. Hebert, Université Laval, Canada

Georges St. Laurent, St. Laurent

Institute, USA

${ }^{*}$ Correspondence:

Minati Singh, 2192 Med Labs, Department of Internal Medicine,

University of lowa, lowa City, IA 52242, USA.

e-mail:minati-singh@uiowa.edu
RNA editing is an alteration in the primary nucleotide sequences resulting from a chemical change in the base. RNA editing is observed in eukaryotic $\mathrm{RRNA}$, transfer RNA, ribosomal RNA, and non-coding RNAs (ncRNA). The most common RNA editing in the mammalian central nervous system is a base modification, where the adenosine residue is basemodified to inosine (A to I). Studies from ADAR (adenosine deaminase that act on RNA) mutants in Caenorhabditis elegans, Drosophila, and mice clearly show that the RNA editing process is an absolute requirement for nervous system homeostasis and normal physiology of the animal. Understanding the mechanisms of editing and findings of edited substrates has provided a better knowledge of the phenotype due to defective and hyperactive RNA editing. A to I RNA editing is catalyzed by a family of enzymes knows as ADARs. ADARs modify duplex RNAs and editing of duplex RNAs formed by ncRNAs can impact RNA functions, leading to an altered regulatory gene network. Such altered functions by $A$ to I editing is observed in mRNAs, microRNAs (miRNA) but other editing of small and long ncRNAs (IncRNAs) has yet to be identified. Thus, ncRNA and RNA editing may provide key links between neural development, nervous system function, and neurological diseases. This review includes a summary of seminal findings regarding the impact of ncRNAs on biological and pathological processes, which may be further modified by RNA editing. NcRNAs are non-translated RNAs classified by size and function. Known ncRNAs like miRNAs, smallRNAs (smRNAs), PIWl-interacting RNAs (piRNAs), and IncRNAs play important roles in splicing, DNA methylation, imprinting, and RNA interference. Of note, miRNAs are involved in development and function of the nervous system that is heavily dependent on both RNA editing and the intricate spatiotemporal expression of ncRNAs. This review focuses on the impact of dysregulated A to I editing and ncRNAs in neurodegeneration.

Keywords: RNA editing, ADARs, non-coding RNAs, microRNAs, snoRNAs, long non-coding RNA

\section{INTRODUCTION}

Environmental signals provoke changes in gene expression in a mechanism that includes epigenetic-mediated gene regulation (Kubota et al., 2012; Miyake et al., 2012). Epigenetic regulation of gene expression has key roles in development, stress responses, and plasticity of the central nervous system (CNS). Epigenetic modifications include RNA editing and chromatin remodeling (i.e., histone modifications), and DNA methylation (Zhou et al., 2008; Luco and Misteli, 2011; Luco et al., 2011). Increasing evidence demonstrates that long non-coding RNAs (lncRNAs) are directed to the sites of action in the genome, suggesting that lncRNAs may be involved in regulation of methylation and chromatic remodeling (Luco and Misteli, 2011; Luco etal., 2011). In the CNS, dysregulation of these critical epigenetic processes leads to the pathogenesis of a broad range of neurological and psychiatric diseases (Mattick and Gagen, 2001; Clark, 2007).

Numerous classes of regulatory non-coding RNA (ncRNA) molecules contribute to the intricate biological system organization and gene regulatory networks that collectively allow normal functioning of the CNS. Dysregulation of these complex gene regulatory networks plays a significant role in the pathogenesis of common neurodegenerative disease such as Alzheimer's disease (AD), Parkinson disease (PD), Huntington disease (HD), and amyotrophic lateral sclerosis (ALS; Akbarian et al., 1995b; Hideyama et al., 2012). In eukaryotes, a unifying theme in all of these genetic diseases is alterations in RNA regulation at multiple levels, including transcriptional changes, RNA editing (Burns et al., 1997; Emeson and Singh, 2001; Bass, 2002; Blow et al., 2006; Beal et al., 2007; Barraud and Allain, 2012), post-transcriptional gene silencing (Mette et al., 2000; Pal-Bhadra et al., 2002; Matzke et al., 2007; Carthew and Sontheimer, 2009; Ghildiyal and Zamore, 2009), X chromosome dosage compensation (Yang and Kuroda, 2007; Kanduri et al., 2009; Fedoriw et al., 2012), germ cell reprogramming (Migicovsky and Kovalchuk, 2011; Guibert et al., 2012), and para-mutation (Chandler, 2007; Cuzin et al., 2008; Figure 1).

Non-coding RNAs either receive or transmit information (Salta and De Strooper, 2012), which is often achieved by duplex structures formed by base pairing with complementary sequences of RNA and DNA; these duplexes can be in the form of either RNA:RNA or RNA:DNA complexes (Mattick, 2003; Mattick and Makunin, 2005). RNA-induced silencing complexes (RISC) or RNA editing by ADAR (adenosine deaminase that act on RNA) 


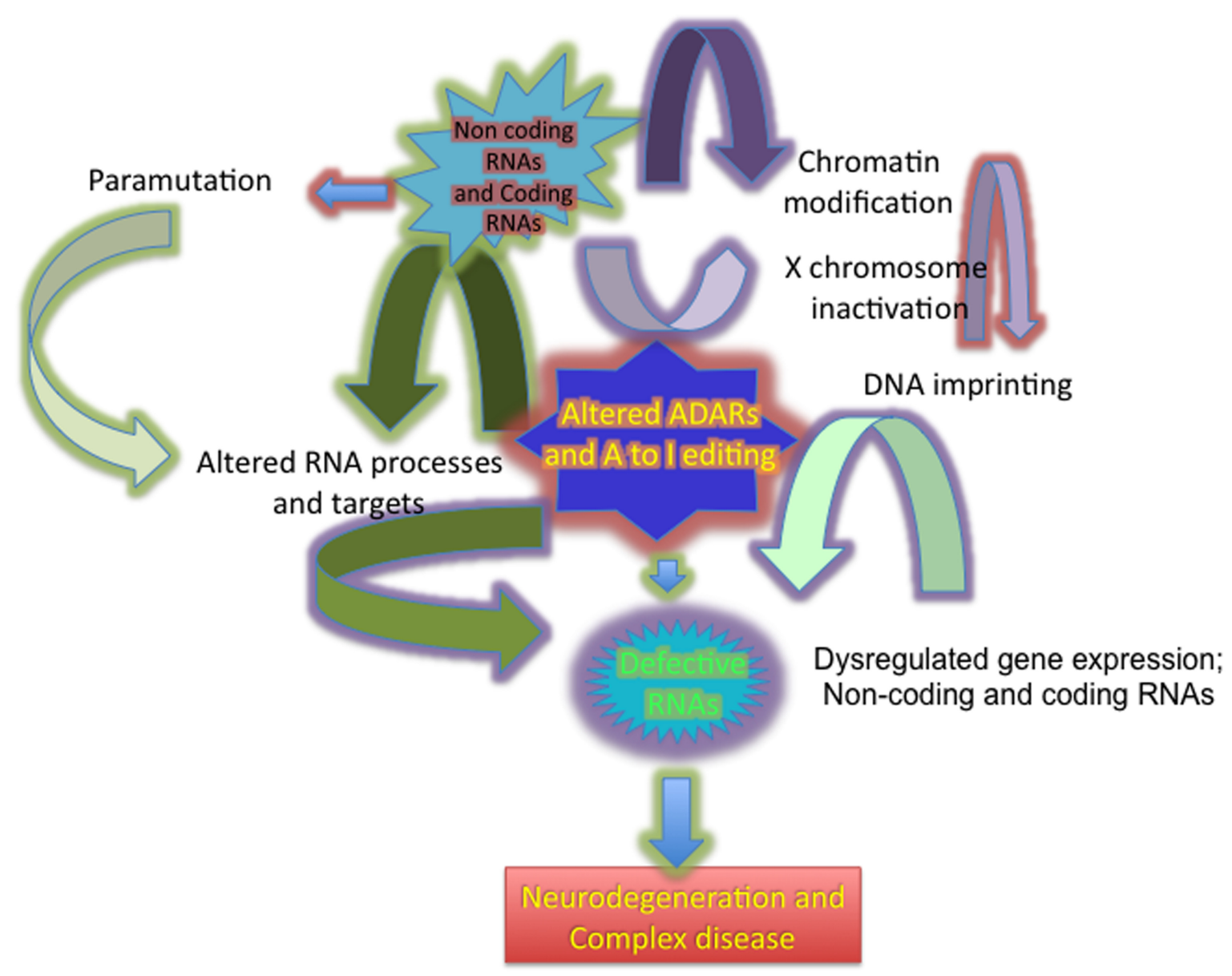

FIGURE 1 | Diagram showing the broad impact of dysregulated ADARs in altering A to I editing, producing defective RNAs and altering gene expression in neurodegeneration.

enzymes recognizes these duplex structures and process them by different mechanisms (Simpson and Emeson, 1996; Bass, 2002; Heale et al., 2009). Intersection of RNA editing in the RNA interference process is observed in both plants and animals (Luciano et al., 2004; Blow et al., 2006; Nishikura, 2006; Heale et al., 2009). Editing is induced by a variety of small ncRNAs such as endogenous small interfering RNAs (siRNAs), PIWI-interacting RNAs (piRNAs), and short transcripts that sit adjacent to promoter (i.e., promoter-associated RNAs; Han et al., 2007) and transcription initiation RNAs (Mehler, 2008). Furthermore, targeted RNA editing in the $3^{\prime}$ untranslated region (UTR) can affect stability, translation, or localization of mRNAs (Kuersten and Goodwin, 2003; Sie and Kuchka, 2011; Irimia et al., 2012). Taken together, these findings support the hypothesis that there is cross talk between RNA editing and the silencing machinery (Scadden and Smith, 2001; Blow et al., 2006; Nishikura, 2006; Ohman, 2007; Heale et al., 2009).

\section{DYSREGULATED A-I EDITING IN NEURODEGENERATION}

Adenosine (A) to inosine (I) conversion in mRNA transcripts (A to I RNA editing) is catalyzed by a family of enzymes known as ADARs. Since inosine has the same base pairing properties as guanosine $(\mathrm{G})$, the transcription and translational machinery recognizes I as a G. Hence, a silent mutation is created at the level of mRNA. In general, A to I editing most frequently targets repetitive RNA sequences located within the introns and $5^{\prime}$ and $3^{\prime}$ UTR to alter both sequence and structure of RNA. A to I editing is widespread and essential for normal life and development (Valente and Nishikura, 2005; Horsch et al., 2011). The ADAR gene family and A-to-I RNA editing deregulation, which results in uncorrected forms of hyper- or hypoediting, has been implicated in a spectrum of neurodevelopmental, neurodegenerative, and neuropsychiatric disorders, strongly suggesting diverse roles in post-transcriptional gene regulation (Valente and Nishikura, 2005).

A to I RNA editing of targeted substrates in the nervous system can alter functional properties of proteins, silence constitutive activity, and modulate RNA translation, localization, and stability (Paul and Bass, 1998; Bass, 2002). In addition to changing codons in mRNA, A to I editing also has the capacity to modulate splicing sites, small nucleolar RNA (sno-RNA) precursors, endogenous antisense RNAs, microRNA (miRNA) target diversity, miRNA and ncRNA processing, and ribonucleoprotein complex targets (Rueter et al., 1999; Bass, 2002; Levanon et al., 2004; Blow et al., 
2006; Kawahara et al., 2006; Kishore and Stamm, 2006; Yang et al., 2006; Heale et al., 2009). ADAR involvement in chromatin modification and possibly in genomic imprinting and X-chromosome inactivation has been proposed, indicating that there is interplay between these processes and RNA-based silencing mechanisms (Fernandez et al., 2005; Valente and Nishikura, 2005). However, when edited mRNA is translated, editing alters biological properties and functions of proteins, such as ligand-gated receptors $\alpha$-amino-3-hydroxy-5-methyl-4-isoxazolepropionic acid (AMPA) receptor (GluR-B subunit), serotonin $2 \mathrm{C}$ receptor, $\mathrm{GABA}_{\mathrm{A}}$ receptor (alpha 3 subunit), and the potassium voltage-gated ion channel KV1.1. It is of note that, they all play an important role in nerve cell function (Emeson and Singh, 2001; Bass, 2002). ADAR2 activity can be modulated by sequestration in the nucleolus and nucleolus-nucleoplasm shuffling (Desterro et al., 2003; Sansam etal., 2003) and ADAR mRNA itself is subject to self-editing, known as auto-editing, which restricts its function in the adult Drosophila and mice (Rueter et al., 1999; Keegan etal., 2005; Feng et al., 2006).

In mammals ADARs are differentially expressed during organogenesis (Paupard etal., 2000; Jacobs etal., 2009). ADAR3 is restricted to the brain, whereas ADAR2 and ADAR1 are ubiquitously expressed but preferentially expressed in the CNS (Bass, 2002). During progressive stages of nervous system maturation, RNA editing also displays complex and dynamic profiles of subcellular localization and spatiotemporal expression (Bernard et al., 1999; Paupard et al., 2000; Sansam et al., 2003; Jacobs et al., 2009). Furthermore, both the behavioral state and genetic background can modify RNA editing (Englander etal., 2005). Changing environmental signals including inflammation and feedback regulation also modifies the activity and molecular profiles of ADARs (Bass, 2002; Yang et al., 2003; Valente and Nishikura, 2005). The potential central roles of RNA editing in brain evolution as well as gene-environmental interactions during nervous system neural maturation comes from studies showing environmentally responsive forms of ADARs. Specifically, the p150 long cytoplasmic isoform of ADAR1, which selectively targets endogenous antisense RNA pathways, is interferon-inducible, and ADAR3 exhibits selective regional, developmental, and mature nervous system expression. Taken together, these data identify unique modulatory roles and substrate specificity for ADARs (Melcher et al., 1996; Chen et al., 2000). ADAR2 has been found to contain inositol hexaphosphate $\left(\mathrm{IP}_{6}\right)$ buried within its enzyme core (Macbeth et al., 2005). Moreover, amino acids that coordinate $\mathrm{IP}_{6}$ in ADAR2 are also conserved in adenosine deaminases that act on transfer RNAs (ADATs), and $\mathrm{IP}_{6}$ is required for ADAT activity (Macbeth et al., 2005), thereby linking ADAR2 to cell signaling pathways.

Multiple isoforms of ADAR1 and ADAR2 exists in the cell (Bass, 2002). ADAR1 displays preferential tissue-specific promoter utilization, whereas ADAR2 exists as multiple spliced isoforms generated by alternative splicing, which results in expression of a broad array of protein species with unique enzymatic properties and remarkable molecular diversity (George et al., 2005; Kawahara et al., 2005). ADARs are normally found as functional dimers that can either homo or hetero dimerize with their own isoforms (Chilibeck et al., 2006; Poulsen et al., 2006; Valente and Nishikura, 2007). However, dimerization of ADAR3 requires additional CNS environmental cues (Cho et al., 2003). Different ADARs can also edit multiple different sites on the same RNA species, resulting in diverse functional outcomes (Valente and Nishikura, 2005). Studies with transgenic mouse embryos that are deficient in both ADAR and ADARB1 activity revealed that deficiency of ADARB1 leads to accumulation of specific miRNAs and corresponding targets, thereby suggesting an important role for ADARs in miRNA biogenesis (Luciano et al., 2004; Yang et al., 2006; Ohman, 2007; Heale et al., 2009; Alon et al., 2012; Vesely etal., 2012). Furthermore ADARs binding alone can affect miRNA biogenesis and function and RNA interference in the nervous system (Heale et al., 2009; Paro et al., 2012). The biological roles of ADAR3 are particularly interesting due to its broad substrate specificity (binding singlestranded as well as double-stranded RNA) and localization that is restricted to brain regions and post-mitotic neurons (Melcher et al., 1996; Chen et al., 2000). ADAR3 can act as a dominant negative regulator for both ADAR1 and ADAR2 activity in vitro, thereby suggesting that correct expression levels of ADARs are required for optimal editing. Furthermore, ADAR3 can form heterodimers with both ADAR1 and ADAR2, providing mechanistic insight into the functional complexity associated with these enzymes in the brain (Chen et al., 2000).

A to I editing occurs more frequently in human transcripts than that was previously hypothesized. The majority of editing is now known to be in the Alu repeats, which are found in introns, intergenic transcripts, and UTRs and are believed to form duplex structures with ncRNAs (Athanasiadis et al., 2004; Kim et al., 2004b; Levanon et al., 2004; Blow et al., 2006). The most abundantly edited human transcripts are predominantly confined to the primate-specific Alu repeats, which are found in thousands of genes (Neeman et al., 2006; Chen and Carmichael, 2008; Chen et al., 2008). Interestingly, the editing levels in mouse and humans differ due in part to a higher divergence of mouse small interspersed nuclear elements (SINE) repeats and primate-specific Alu repeats (Alon et al., 2012; Vesely et al., 2012). However, two recent studies that estimated the total level of editing in the mouse have found that this is not the case (Kim et al., 2004a; Eisenberg et al., 2005). It is important to note that other mammals have a similar number of different SINEs but display lower editing levels as compared to humans (Morse et al., 2002; Waterston et al., 2002; Mattick, 2003; Kim et al., 2004a; Eisenberg et al., 2005; Mattick and Makunin, 2005; Matzke et al., 2007; Mehler, 2008; Ghildiyal and Zamore, 2009). For example, structured mRNAs or mRNAs with edited $3^{\prime}$ UTRs interact with P54 ${ }^{\text {nrb }}$ complexes and are retained in the nucleus (Chen and Carmichael, 2008). In mouse, CAT2 transcribed nuclear RNA (CTN-RNA), whose $3^{\prime}$ UTR is edited, is localized to paraspeckles (Prasanth et al., 2005). Studies utilizing eukaryotic mutants show that A to I RNA editing is an absolute requirement for normal functioning of the nervous system (Reenan, 2001; Tonkin et al., 2002; Wang et al., 2004a). Not surprisingly, deregulation of RNA editing results in dysregulation of the nervous system (Kwak and Kawahara, 2005; Valente and Nishikura, 2005). Abnormal RNA editing has been implicated in epilepsy, schizophrenia, depression, suicide, prion-induced neurodegeneration, autosomal dominant episodic ataxia type I, Prader Willi syndrome (PWS), ALS, AD, and HD (Niswender et al., 1999; Sodhi et al., 2001; Gurevich et al., 2002; Iwamoto and Kato, 
2003; Englander et al., 2005; Iwamoto et al., 2005; Kwak and Kawahara, 2005; Valente and Nishikura, 2005; Kishore and Stamm, 2006; Doe etal., 2009; Morabito etal., 2010; Singh etal., 2011; Kiesel et al., 2012).

Brain region-specific changes at the $Q / R$ editing site of the GluR-B transcript have been described in both $\mathrm{AD}$ and $\mathrm{HD}$ (Akbarian et al., 1995a,b; Wright and Vissel, 2012). The pathology of sporadic ALS, a progressive neurodegenerative disease of the motor neurons, is due to glutamate excito-toxicity, where increased glutamate levels activate glutamate-gated ion channels that results in excessive $\mathrm{Ca}^{++}$influx and neuronal death. Of note, A to I RNA editing has been implicated in excessive $\mathrm{Ca}^{++}$influx in ALS. Recently, it has been shown that there is a strong correlation between increased editing in EAAT2 pre-mRNA and activation of alternative poly A site in the motor cortex of ALS patients (Flomen and Makoff, 2011). On the other hand, ALS patients also have decreased editing of the Q/R site in GluR-B transcripts of spinal motor neurons (62-100\% relative to controls with $100 \%$ editing; Kwak and Kawahara, 2005; Kwak et al., 2008). Collectively, these observations suggest a differential deregulation of A to I editing in ALS likely leads to disturbances in the $\mathrm{Ca}^{++}$permeability and neuronal cell death characteristic of this disease (Akbarian et al., 1995b).

Pharmacological studies provide a clear role for serotonin in psychiatric disorders such as schizophrenia, depression, and anxiety (Kennett etal., 1997; Martin etal., 1998). Editing of the $5 \mathrm{HT}_{2 \mathrm{C}} \mathrm{R}$ mRNA is involved in the pathophysiology of psychotic disorders. Specifically, editing regulates the efficacy of hallucinogenic and antipsychotic drugs on the $5 \mathrm{HT}_{2 \mathrm{C}} \mathrm{R}$ (Sodhi et al., 2005). Abnormal editing of the $5 \mathrm{HT}_{2 \mathrm{C}} \mathrm{R}$ is associated with hyperphagia, schizophrenia, depression, and suicide in humans (Niswender et al., 1999; Sodhi et al., 2001; Gurevich et al., 2002; Iwamoto and Kato, 2003; Morabito et al., 2010) and abnormal editing is also observed in animal models of affective disorders and PWS-like (Englander et al., 2005; Iwamoto et al., 2005; Kishore and Stamm, 2006; Doe etal., 2009; Morabito et al., 2010; Singh et al., 2011). In animals, $5 \mathrm{HT}_{2} \mathrm{C}$ editing is sensitive to stress and medication as well as the genetic background and behavioral state of animals (Iwamoto et al., 2005; Du et al., 2006; Gardiner and Du, 2006; Hackler et al., 2006). These studies imply that animal models may provide additional insights into the relationship between editing of the $5 \mathrm{HT}_{2} \mathrm{C}$ and clarify findings from postmortem brains of patients with mental disorders. Given to the functional implications of RNA editing of substrates implicated in these diseases, the ADAR enzymes represent novel targets to treat psychiatric disorders.

\section{DYSREGULATED ncRNAs IN NEURODEGENERATION}

Research in the role of ncRNAs in neurodegeneration has exploded in recent years, with several in-depth review articles available (Mattick and Makunin, 2006; Mehler and Mattick, 2007; Dinger et al., 2008; Mattick and Mehler, 2008; Eacker et al., 2009; Lau and de Strooper, 2010; Sonntag, 2010; Bian and Sun, 2011; Qureshi and Mehler, 2011, 2012; Enciu et al., 2012; Junn and Mouradian, 2012; Saito and Saito, 2012). In the following sections, an overview of the impact of dysregulated ncRNAs in neurodegeneration is provided, with a focus on the role of RNA editing in the pathophysiology. To date, RNA editing has only been documented in miRNAs, but it is highly plausible that RNA editing occurs in other ncRNA species. Thus, also included is a description of key research findings in the role of other ncRNAs, such as snoRNAs and $\ln R N A s$, in neurodegenerative diseases. These ncRNA species are ripe for research to analyze whether RNA editing might impact their expression and activity. Furthermore, the fact that binding of ADARs in the absence of editing also affects miRNA biogenesis supports the hypothesis that ADARs can interfere with the function of other ncRNAs.

\section{DYSREGULATED mIRNAs IN NEURODEGENERATION}

The biological significance of edited ncRNAs remains unknown. However, the possibility of a role in RNA interference is likely (Haramati et al., 2010; Hansen et al., 2012). RNA editing regulates precursor miRNAs that play a role in the biogenesis and function of certain miRNAs, which are abundantly edited by ADARs (Alon et al., 2012; Vesely et al., 2012). Several pri-miRNA are A to I edited, which can prevent processing at either stages or modify the targets of the final RISC complex (Kawahara et al., 2007). The fact that neural defects including tremors and neurodegeneration are present in ADAR-knockout Drosophila melanogaster makes a strong case for requirement of regulated A to I editing for normal behavior and nervous system functioning (Palladino et al., 2000; Keegan et al., 2005; Jepson and Reenan, 2010).

Non-coding RNAs, such as miRNAs, siRNAs, and piRNAs all guide effector Argonaute protein to either genomic loci or target RNAs in a sequence-specific manner (Mattick, 2003; Mattick and Makunin, 2005; Pang et al., 2006). Development and neural cell differentiation are regulated by brain-specific miRNAs (Haramati et al., 2010; Hansen et al., 2012). In the adult brain at various time points, miRNAs are known to regulate neural function and synaptic plasticity. Expression of miRNAs are tightly regulated during developmental processes, cell proliferation, neuronal gene expression, brain morphogenesis, neural cell fate, apoptosis, and stem cell division (Mattick, 2003; Mattick and Makunin, 2005; Matzke et al., 2007; Mehler, 2008; Ghildiyal and Zamore, 2009). The brain displays both temporal and region-specific miRNA expression, and the most abundant miRNA expression is observed in cerebellum and cerebral cortex (Haramati et al., 2010; Hansen et al., 2012). Depending on where miRNAs are localized, distinct miRNAs are also involved in memory formation (Hansen et al., 2012).

MicroRNAs can be derived from either the introns or exons of both protein-coding and ncRNAs transcribed by RNA polymerase II. Processed small hairpin RNAs or double-stranded RNA precursors give arise to miRNAs that are generally 22nt long (Bartel, 2004). miRNAs that contain 21-23 nucleotide regulatory sequences inhibit translation of targeted mRNA by base pairing with the targeted regions in the mRNA (Pal-Bhadra et al., 2002; Kuersten and Goodwin, 2003; Nishikura, 2006; Carthew and Sontheimer, 2009). A number of miRNAs are associated with neuropsychiatric diseases via silencing of targets involved in disease development. Perturbations of miRNA expression, sequence, or target sites are all associated with numerous neuronal diseases. During neuroblast differentiation, double-stranded RNA silencing element exclusive to neuronal cells, i.e., mir-124a, dictates transcriptional activation of a silencing factor (NRSF; Chen 
et al., 2012). Increased expression of mir-21 is linked to glioblastoma (Wang et al., 2012). Deregulated DGCR8 expression, which is associated with DiGeorge syndrome (Chen et al., 2012), is involved in miRNA processing and in learning disability. Tourette's syndrome is associated with sequence variations in mir-189, which targets SLIT (axonal growth-controlling protein SLIT) in a mechanism that includes alterations in the miR-189 binding site in SLIT and Trk-like family member1 (SLITRK-1) mRNA (Abelson et al., 2005), a protein that is essential for neuronal growth, guidance, and neurite branching. Deregulated mir-175 expression has been linked to the X-linked mental retardation (MRX3), which resembles an early onset PD. In Waisman syndrome, disruption of the $3^{\prime}$ UTR of fibroblast growth factor 20 (FGF20) by a mutation alters the recognition site of mir-433, which results in increased translation of FGF20 and is correlated with increased alpha-synuclein expression (Dostie et al., 2003; Wang et al., 2008; Harraz et al., 2011). All together these studies suggest that alterations in miRNA expression lead to dysregulated neuronal functioning.

\section{DYSREGULATED SMALL NUCLEOLAR RNAs IN NEURODEGENERATION}

While a role for ADARs in other ncRNAs has not been reported, ncRNAs form secondary structures that might be recognized by ADARs. Thus, it is possible that RNA editing or ADAR binding might alter structure and function of other ncRNAs described in the following sections. SnoRNAs range from 60 to 300 nucleotides in length and guide site-specific modification of nucleotides in target RNAs by base pairing with short regions of target RNA. SnoRNAs can be divided into two major classes: the box C\D snoRNAs, which guide 2 '-O-ribose-methylation, and H/ACA snoRNAs that guide pseudouridylation of target RNAs (Kiss et al., 2002, 2004). Another group known as orphan snoRNAs because of their unknown RNA targets have been identified. Targets include ribosomal RNA (rRNA), small nuclear (snRNAs), and mRNAs (Pang et al., 2006). Mammalian snoRNAs are derived from introns of coding or non-coding genes (Meier, 2005). ClD snoRNAs are localized to nucleolus, whereas H/ACA snoRNAs are localized to cajal bodies. snoRNAs exhibit tissue-specific, developmental, and imprinting-regulated expression (Rogelj and Giese, 2004).

A number of brain-specific snoRNAs have been identified in mice including MBI-36, MBII-13, MBII-48, MBII-49, MBII-52, MBII-78, and MBII-85 (Ding et al., 2005). These snoRNAs display brain region-specific expression and play crucial roles in gene regulation and normal physiology. Similarly homolog of these snoRNAs is also highly enriched in the human brain. Some of these snoRNAs have been shown to be associated with contextual memory consolidation (fear conditioning; Rogelj et al., 2003). Interestingly, snoRNA MBII-52 targets the serotonin $2 \mathrm{C}$ receptor $\left(5 \mathrm{HT}_{2} \mathrm{C}\right)$ and regulates alternative splicing and editing of the $5 \mathrm{HT}_{2 \mathrm{C}} \mathrm{R}$ (Kishore and Stamm, 2006). As described above, editing of the $5 \mathrm{HT}_{2} \mathrm{C}$ has been implicated in depression, anxiety, schizophrenia, and feeding regulation (Niswender et al., 1999; Sodhi et al., 2001; Gurevich et al., 2002; Iwamoto and Kato, 2003; Hackler et al., 2006; Singh et al., 2007, 2009, 2011). Abnormal MBII-52 and MBII-85 snoRNA expression (Ding et al., 2005; Kishore and Stamm, 2006; Kishore et al., 2010) and A to I editing of the $5 \mathrm{HT}_{2} \mathrm{C}$ editing are all implicated in PWS and obesity
(Kishore and Stamm, 2006; Kishore et al., 2010; Morabito et al., 2010; Schellekens et al., 2012). Of note, ADAR2 is sequestered in the nucleolus (Desterro et al., 2003; Sansam et al., 2003), and ADAR2-mediated editing of RNA substrates in the nucleolus is inhibited by snoRNAs (Vitali et al., 2005). Taken together, these multiple studies suggest that a very complex RNA regulatory network maintains homeostasis in the CNS (Kishore and Stamm, 2006; Kishore et al., 2010). It is unclear how editing or splicing of the $5 \mathrm{HT}_{2} \mathrm{C}$ contributes to pathogenesis of PWS. However, the snoRNA SNORD-52 involvement of RNA editing and splicing of the $5 \mathrm{HT}_{2} \mathrm{C}$ and the abnormal pattern of expression of the $5 \mathrm{HT}_{2} \mathrm{C}$ or altered edited $5 \mathrm{HT}_{2} \mathrm{C}$ ratio in PWS suggests that a compromised 5-HT signaling might contribute to pathogenesis of the disease (Cavaille et al., 2000, 2002; Kishore and Stamm, 2006; Kishore et al., 2010). This idea is supported by data in genetically modified mice expressing only the fully edited $5 \mathrm{HT}_{2 \mathrm{C}} \mathrm{R}$, which mimics a PWS-like phenotype (Morabito et al., 2010). In addition, many other snoRNAs are mapped to the Prader Willi locus such as HBII-13, HBII-52, and HBII-85, and these may also be involved in or be regulated by imprinting (Rogelj and Giese, 2004).

\section{DYSREGULATED LONG NON-CODING RNAs IN NEURODEGENERATION}

Numerous brain-specific lncRNAs are alternatively spliced, developmentally regulated, and are physiologically responsive (Furuno etal., 2006; Kapranov etal., 2007). IncRNAs that are derived from the mammalian genome are both polyadenylated and nonpolyadenylated (Mattick and Gagen, 2001; Huang et al., 2012; Song et al., 2012). Imprinting and antisense transcription of lncRNAs that host genes for miRNAs and snoRNAs that are localized to the nucleus of nervous tissue suggest that these lncRNAs may be involved in gene regulation (Furuno et al., 2006). The transcription patterns of lncRNAs are in complex intergenic, overlapping, and antisense patterns relative to adjacent protein-coding genes (Satoh, 2012; Tran et al., 2012). Thus, it is possible that the lncRNAs regulate the expression of those genes. LncRNAs are involved in the formation and function of cellular organelles that are regulated transcriptionally and developmentally in a cell-specific manner (Satoh, 2012; Tran et al., 2012). The functions of numerous lncRNAs are not known but studies suggest that they play an important role in cell identifying the neuronal and glial cells in the CNS (Mercer et al., 2010).

Patients with HD have widespread changes in their brain gene regulatory networks (Ideker and Sharan, 2008). These changes include non-protein coding RNAs and protein coding RNAs. Seven lncRNAs in the human brain are specifically dysregulated in HD (Johnson, 2012). New findings suggest that, besides protein-coding genes, ncRNAs also contribute to neurodegenerative processes. Evidence for a role for ncRNAs in HD comes from the genome-wide data where novel, non-coding targets of RE1-silencing transcription factor (REST) were discovered (Buckley et al., 2010; Johnson et al., 2010). A human accelerated region 1 (HAR1) specifically is transcribed in the nervous system. REST is targeted to the HAR1 locus that is recognized by specific DNA regulatory motifs and results in potent transcriptional repression. Aberrant nuclear localization of the master transcriptional repressor REST disrupts the gene regulatory networks in 
the neurons of HD patients. Notably, HAR1 levels are significantly lower in the striatum of HD patients compared with unaffected individuals. Interestingly, many of these lncRNAs contain genomic binding sites for the transcriptional repressor REST, a key mediator of transcriptional changes in HD, including the known REST target lncRNA, DGCR5. LncRNAs TUG1 (necessary for retinal development), and NEAT1 (a structural component of nuclear paraspeckles) are upregulated in HD caudate, while the brain-specific tumor-suppressor MEG3 is downregulated in HD (Johnson, 2012). Formation of epigenetic ribonucleoprotein complexes, including lncRNAs TUG1 and MEG3, regulates gene expression. All together these findings suggest that changes in lncRNA expression are widespread in HD, contributing to altered epigenetic gene regulation in diseased neurons and likely corresponding neurodegeneration. Thus, studying the regulation of non-coding gene expression changes and lncRNA network changes in HD may provide a better understanding of and suggest novel treatments for not only HD but also other neurodegenerative processes. For example, the lncRNA BACE 1 has been directly implicated in upregulation of amyloid-beta 1-42 in AD (Faghihi etal., 2008). Thus lncRNAs play an important role in regulating gene expression for normal functioning of the nervous system.

\section{DYSREGULATED IMPRINTED NON-CODING RNAs IN NEURODEGENERATION}

Imprinted genes are known to play essential roles in both neural development and adult CNS functioning. Alterations in their expression profiles are linked to a spectrum of complex neurodevelopment and neuropsychiatric disorders (Costa, 2005; Davis et al., 2005). These allele-selective genes exhibit preferential and exquisite cell-specific patterns of expression within the brain and are frequently processed from larger transcriptional units that encompasses multiple tandem repeats of snoRNAs and miRNAs (Sleutels etal., 2000; Costa, 2005; Davis et al., 2005; Lewis and Reik, 2006). These imprinted loci usually generate a complex spectrum of spliced and unspliced larger ncRNAs of unknown function (Sleutels etal., 2000; Costa, 2005; Davis et al., 2005; O'Neill, 2005; Furuno et al., 2006). Additional ncRNAs are associated with imprinted loci that include the production of antisense RNAs to reciprocally imprinted neighboring protein-coding genes (Sleutels et al., 2000; Davies et al., 2005). The role of imprinted genes in regulating distinct brain signaling systems and in mediating brain-behavior relationships can be deduced from spectrum of neurological diseases caused by disruptions in imprinted loci: PWS and Angelman syndromes, autism, schizophrenia, attention deficit hyperactivity disorder, bipolar disorder, and Tourette's syndrome (Davies et al., 2004, 2005, 2006; Wang et al., 2004b).

\section{DYSREGULATED TRANSFER AND RIBOSOMAL RNAs IN NEURODEGENERATIVE DISEASE}

Adenosine deaminase that act on RNA have the ability to act in concert with ADATs to modify transfer RNAs (tRNAs) to change codon recognition. Interestingly, a mutation in the "editing" domain of a specific aminoacyl-tRNA synthetase results in mischarged tRNAs, intracellular accumulation of misfolded proteins in neurons, and induction of the endoplasmic reticulum-mediated unfolded protein stress response with associated neurodegeneration (Lee et al., 2006). tRNAs and rRNAs are implicated in a broad array of neural developmental and mature CNS functions. Not surprisingly, therefore, mutations in these two classes of ncRNAs underlie a range of neurodevelopment, neurodegenerative, and neuropsychiatric diseases. Such examples include chronic progressive external ophthalmoplegia (CPEO), Kearn-Sayre syndrome (KSS: CPEO with retinal degeneration), mitochondrial myopathy, encephalopathy, lactic acidosis, and stroke (MELAS) syndrome that manifests in mitochondrial encephalopathy with stroke-like syndromes and migraine headaches, myoclonic epilepsy with ragged red fibers (MERRF) syndrome that results in myoclonus epilepsy, mitochondrial myopathy, cerebella ataxia (Dimauro, 2004; Dimauro and Davidzon, 2005; Fattal et al., 2006), and motor neuron disease (Borthwick et al., 2006). Other tRNA-mediated neuropsychiatric diseases include schizophrenia, psychosis, delirium, personality disorders, major depressive disorders, and anxiety disorders (Fattal et al., 2006). Besides tRNA-associated diseases, deregulated rRNA is also implicated in RNA oxidation of vulnerable neurons in $\mathrm{AD}$ (Honda et al., 2005).

\section{DYSREGULATED RNA TRINUCLEOTIDE EXPANSIONS IN NEURODEGENERATION}

The expansion of trinucleotide repeats caused by RNA-mediated mechanisms is associated with neurodegenerative diseases (Gallo et al., 2005; Gatchel and Zoghbi, 2005). Dramatically expanded (>200) CGG repeats in the $5^{\prime}$ UTR of the Fmrl gene results in fragile $\mathrm{X}$ syndrome. The related disease is also associated with smaller (60-200) trinucleotide repeat expansion called fragile X tremor/ataxia syndrome (FXTAS). FXTAS is associated with tremor, cerebella ataxia, cognitive decline, peripheral neuropathy, $\mathrm{PD}$, autonomic dysfunction, proximal muscle weakness, multisystem atrophy, and dementia (Hagerman et al., 2005; Van Esch, 2006). Myotonic dystrophy, another trinucleotide disorder, is predominantly a muscle disorder which exists in two neurological forms: DM1 with mental retardation, memory, visuo-spatial, and executive dysfunction, and DM2 with preferential executive dysfunction (D'Angelo and Bresolin, 2006). DM1 is associated with CTG expansion within the $3^{\prime}$ UTR of the dystrophia myotonica protein kinase (DMPK) gene, and DM2 is linked to CCTG expansion in intron 1 of the zinc finger protein gene ZNF9 (Brook et al., 1992; Fu et al., 1992; Mahadevan et al., 1992; Ranum et al., 1998). These mutant RNAs orchestrate different forms of pathogenesis depending on the degree and type of expanded repeat length and their molecular interactions with the muscleblindlike (MBNL) family of RNA-binding proteins (Jiang et al., 2004; Pascual et al., 2006).

Several forms of spinocerebellar ataxia (SCA) are also implicated in different RNA-mediated pathological mechanisms. SCA8 results from CTG expansion of the $3^{\prime}$ UTR of an untranslated antisense RNA with partial overlap with the Kelch-like 1 (KLHL1) gene (Koob et al., 1999; Nemes et al., 2000; Mutsuddi et al., 2004; Gatchel and Zoghbi, 2005). Utilizing SCA8 as a modifier screen, four novel ncRNAs have been identified that show preferential neuronal expression (Mutsuddi et al., 2004). SCA10 is mediated by an unstable ATTCT repeat expansion in the $3^{\prime}$ end of a 
large intron of a gene of unknown function that may result in transcriptional silencing or in a different RNA-associated toxic mechanism (Matsuura etal., 2000). SCA12 is caused by CAG expansion in the non-coding $5^{\prime}$ promoter or $5^{\prime}$ UTR of the PPP2R2B gene, which encodes a brain-specific regulatory subunit of protein phosphatase 2A (Holmes et al., 1999). All together these findings suggest that, depending on where the expanded trinucleotide repeat is localized, disease pathogenesis is likely mediated by distinct trans-dominant RNA or alternatively by toxic gain of function mechanisms (Holmes et al., 2003). Taken together, these studies suggest that elucidating the lncRNA network is an important step toward understanding neurodegeneration and may reveal new targets to treat neurodegenerative diseases.

\section{SUMMARY}

RNA is a carrier of information and plays a central role in regulating development. A variety of regulatory non-protein-coding RNA molecules form complex multi-layered biological systems. A gene regulatory network that allows normal functioning of the CNS governs this complex system. A deregulated complex gene regulatory network plays a significant role in common neurodegenerative diseases. Furthermore, the list of known ncRNAs

\section{REFERENCES}

Abelson, J. F., Kwan, K. Y., O’Roak, B. J., Baek, D. Y., Stillman, A. A., Morgan, T. M., et al. (2005). Sequence variants in SLITRK1 are associated with Tourette's syndrome. Science $310,317-320$.

Akbarian, S., Huntsman, M. M., Kim, J. J., Tafazzoli, A., Potkin, S. G., Bunney, W. E., Jr., et al. (1995a). GABAA receptor subunit gene expression in human prefrontal cortex: comparison of schizophrenics and controls. Cereb. Cortex 5, 550-560.

Akbarian, S., Smith, M. A., and Jones, E. G. (1995b). Editing for an AMPA receptor subunit RNA in prefrontal cortex and striatum in Alzheimer's disease, Huntington's disease and schizophrenia. Brain Res. 699, 297-304.

Alon, S., Mor, E., Vigneault, F., Church, G. M., Locatelli, F., Galeano, F., et al. (2012). Systematic identification of edited microRNAs in the human brain. Genome Res. 22, 15331540.

Athanasiadis, A., Rich, A., and Maas, S. (2004). Widespread A-to-I RNA editing of Alu-containing mRNAs in the human transcriptome. PLoS Biol. 2:e391. doi: 10.1371/journal.pbio.0020391

Barraud, P., and Allain, F. H. (2012). ADAR proteins: double-stranded RNA and Z-DNA binding domains. Curr. Top. Microbiol. Immunol. 353, 35-60.

Bartel, D. P. (2004). MicroRNAs: genomics, biogenesis, mechanism, and function. Cell 116, 281-297.
Bass, B. L. (2002). RNA editing by adenosine deaminases that act on RNA. Annu. Rev. Biochem. 71, 817846.

Beal, P. A., Maydanovych, O., and Pokharel, S. (2007). The chemistry and biology of RNA editing by adenosine deaminases. Nucleic Acids Symp. Ser. (Oxf) 83-84.

Bernard, A., Ferhat, L., Dessi, F., Charton, G., Represa, A., BenAri, Y., etal. (1999). Q/R editing of the rat GluR5 and GluR6 kainate receptors in vivo and in vitro: evidence for independent developmental, pathological and cellular regulation. Eur. J. Neurosci. 11, 604-616.

Bian, S., and Sun, T. (2011). Functions of noncoding RNAs in neural development and neurological diseases. Mol. Neurobiol. 44, 359-373.

Blow, M. J., Grocock, R. J., Van Dongen, S., Enright, A. J., Dicks, E., Futreal, P. A., et al. (2006). RNA editing of human microRNAs. Genome Biol. 7, R27.

Borthwick, G. M., Taylor, R. W., Walls, T. J., Tonska, K., Taylor, G. A., Shaw, P. J., et al. (2006). Motor neuron disease in a patient with a mitochondrial tRNAIle mutation. Ann. Neurol. 59, 570-574.

Brook, J. D., Mccurrach, M. E., Harley, H. G., Buckler, A. J., Church, D., Aburatani, H., et al. (1992). Molecular basis of myotonic dystrophy: expansion of a trinucleotide (CTG) repeat at the $3^{\prime}$ end of a transcript encoding a protein kinase family member. Cell $68,799-808$.

implicated in mammalian brain health and disease is growing. RNA can alter the information in the genetic code without altering the hard-wired DNA through splicing and RNA editing. ADAR substrates involved in RNA editing mechanisms provide functional complexity. RNA editing mediates the environmental cues by transmitting information to the epigenome. This mechanism connects the environment to the genome and plays important roles in a broad range of processes, from evolution to learning and memory. A to I RNA editing, besides altering protein function, also has the potential to alter splice site choice, miRNA target diversity, miRNA processing, and perhaps chromatin architecture. Furthermore, RNA editing alters RNA structure and thereby could potentially impact the biological functions of multiple types of ncRNAs. Therefore, RNA editing, RNA modification, small and long ncRNAs, and their complex regulatory network lead to a unifying theme of RNA-mediated regulatory circuitry for normal brain function.

\section{ACKNOWLEDGMENTS}

This research is supported by National Institute of Mental Health (MS) MH082234-02. The author would like to thank Dr. Kristina Thiel for critically reviewing the manuscript.

Buckley, N. J., Johnson, R., Zuccato, C., Bithell, A., and Cattaneo, E. (2010). The role of REST in transcriptional and epigenetic dysregulation in Huntington's disease. Neurobiol. Dis. 39, 28-39.

Burns, C. M., Chu, H., Rueter, S. M., Hutchinson, L. K., Canton, H., Sanders-Bush, E., et al. (1997). Regulation of serotonin-2C receptor $\mathrm{G}$ protein coupling by RNA editing. Nature 387, 303-308.

Carthew, R. W., and Sontheimer, E. J. (2009). Origins and Mechanisms of miRNAs and siRNAs. Cell 136, 642-655.

Cavaille, J., Buiting, K., Kiefmann, M. Lalande, M., Brannan, C. I., Horsthemke, B., et al. (2000). Identification of brain-specific and imprinted small nucleolar RNA genes exhibiting an unusual genomic organization. Proc. Natl. Acad. Sci. U.S.A. 97, 14311-14316.

Cavaille, J., Seitz, H., Paulsen, M., Ferguson-Smith, A. C., and Bachellerie, J. P. (2002). Identification of tandemly-repeated C/D snoRNA genes at the imprinted human $14 \mathrm{q} 32$ domain reminiscent of those at the Prader-Willi/Angelman syndrome region. Hum. Mol. Genet. 11, 1527-1538.

Chandler, V. L. (2007). Paramutation: from maize to mice. Cell 128 , 641-645.

Chen, C. X., Cho, D. S., Wang, Q., Lai, F., Carter, K. C., and Nishikura, K. (2000). A third member of the RNA-specific adenosine deaminase gene family, ADAR3, contains both single- and double-stranded RNA binding domains. RNA 6, 755-767.

Chen, L. L., and Carmichael, G. G. (2008). Gene regulation by SINES and inosines: biological consequences of A-to-I editing of Alu element inverted repeats. Cell Cycle 7, 3294-3301.

Chen, L. L., Decerbo, J. N., and Carmichael, G. G. (2008). Alu element-mediated gene silencing. EMBO J. 27, 1694-1705.

Chen, Z., Wu, J., Yang, C., Fan, P., Balazs, L., Jiao, Y., et al. (2012). DiGeorge syndrome critical region 8 (DGCR8) protein-mediated microRNA Biogenesis Is Essential for Vascular Smooth Muscle Cell Development in Mice. J. Biol. Chem. 287, 19018-19028.

Chilibeck, K. A., Wu, T., Liang, C., Schellenberg, M. J., Gesner, E. M., Lynch, J. M., et al. (2006). FRET analysis of in vivo dimerization by RNA-editing enzymes. J. Biol. Chem. 281, 16530-16535.

Cho, D. S., Yang, W., Lee, J. T., Shiekhattar, R., Murray, J. M., and Nishikura, K. (2003). Requirement of dimerization for RNA editing activity of adenosine deaminases acting on RNA. J. Biol. Chem. 278, 1709317102.

Clark, S. J. (2007). Action at a distance: epigenetic silencing of large chromosomal regions in carcinogenesis. Hum. Mol. Genet. 16, R88-R95.

Costa, F. F. (2005). Non-coding RNAs: new players in eukaryotic biology. Gene 357, 83-94. 
Cuzin, F., Grandjean, V., and Rassoulzadegan, M. (2008). Inherited variation at the epigenetic level: paramutation from the plant to the mouse. Curr. Opin. Genet. Dev 18, 193-196.

D’Angelo, M. G., and Bresolin, N. (2006). Cognitive impairment in neuromuscular disorders. Muscle Nerve 34, 16-33.

Davies, W., Isles, A. R., Burgoyne, P. S., and Wilkinson, L. S. (2006). $\mathrm{X}$-linked imprinting: effects on brain and behaviour. Bioessays 28, 35-44.

Davies, W., Isles, A. R., and Wilkinson, L. S. (2005). Imprinted gene expression in the brain. Neurosci. Biobehav. Rev. 29, 421-430.

Davies, W., Smith, R. J., Kelsey, G., and Wilkinson, L. S. (2004). Expression patterns of the novel imprinted genes Nap115 and Peg13 and their nonimprinted host genes in the adult mouse brain. Gene Expr. Patterns 4, 741-747.

Davis, E., Caiment, F., Tordoir, X., Cavaille, J., Ferguson-Smith, A., Cockett, N., et al. (2005). RNAimediated allelic trans-interaction at the imprinted Rtl1/Peg11 locus. Curr. Biol. 15, 743-749.

Desterro, J. M., Keegan, L. P., Lafarga, M., Berciano, M. T., O'Connell, M., and Carmo-Fonseca, M. (2003). Dynamic association of RNA-editing enzymes with the nucleolus. J. Cell Sci. 116, 1805-1818.

Dimauro, S. (2004). Mitochondrial medicine. Biochim. Biophys. Acta 1659, 107-114.

Dimauro, S., and Davidzon, G. (2005). Mitochondrial DNA and disease. Ann. Med. 37, 222-232.

Ding, F., Prints, Y., Dhar, M. S., Johnson, D. K., Garnacho-Montero, C., Nicholls, R. D., et al. (2005). Lack of Pwcr1/MBII-85 snoRNA is critical for neonatal lethality in Prader-Willi syndrome mouse models. Mamm. Genome 16, 424-431.

Dinger, M. E., Pang, K. C., Mercer, T. R., and Mattick, J. S. (2008). Differentiating protein-coding and noncoding RNA: challenges and ambiguities. PLoS Comput. Biol. 4:e1000176. doi: 10.1371/journal.pcbi.1000176

Doe, C. M., Relkovic, D., Garfield, A. S., Dalley, J. W., Theobald, D. E., Humby, T., et al. (2009). Loss of the imprinted snoRNA mbii-52 leads to increased 5 htr2c pre-RNA editing and altered 5HT2CR-mediated behaviour. Hum. Mol. Genet. 18, 21402148.

Dostie, J., Mourelatos, Z., Yang, M., Sharma, A., and Dreyfuss, G. (2003). Numerous microRNPs in neuronal cells containing novel microRNAs. RNA 9, 180-186.

Du, Y., Davisson, M. T., Kafadar, K., and Gardiner, K. (2006). A-to-I premRNA editing of the serotonin 2C receptor: comparisons among inbred mouse strains. Gene 382, 39-46.

Eacker, S. M., Dawson, T. M., and Dawson, V. L. (2009). Understanding microRNAs in neurodegeneration. Nat. Rev. Neurosci. 10, 837-841.

Eisenberg, E., Nemzer, S., Kinar, Y., Sorek, R., Rechavi, G., and Levanon, E. Y. (2005). Is abundant A-to-I RNA editing primate-specific? Trends Genet. 21, 77-81.

Emeson, R. B., and Singh, M. (2001). "Adenosine to inosine RNA editing: substrates and consequences.," in RNA Editing: Frontiers in Molecular Biology, ed. B. L. Bass (London: Oxford University Press), 109-138.

Enciu, A. M., Popescu, B. O., and Gheorghisan-Galateanu, A. (2012). MicroRNAs in brain development and degeneration. Mol. Biol. Rep. 39, 2243-2252.

Englander, M. T., Dulawa, S. C., Bhansali, P., and Schmauss, C. (2005). How stress and fluoxetine modulate serotonin $2 \mathrm{C}$ receptor pre-mRNA editing. J. Neurosci. 25, 648-651.

Faghihi, M. A., Modarresi, F., Khalil, A. M., Wood, D. E., Sahagan, B. G., Morgan, T. E., et al. (2008). Expression of a noncoding RNA is elevated in Alzheimer's disease and drives rapid feed-forward regulation of beta-secretase. Nat. Med. 14, 723-730

Fattal, O., Budur, K., Vaughan, A. J., and Franco, K. (2006). Review of the literature on major mental disorders in adult patients with mitochondrial diseases. Psychosomatics 47, 1-7.

Fedoriw, A., Mugford, J., and Magnuson, T. (2012). Genomic imprinting and epigenetic control of development. Cold Spring Harb. Perspect. Biol. 4, a008136.

Feng, Y., Sansam, C. L., Singh, M. and Emeson, R. B. (2006). Altered RNA editing in mice lacking ADAR2 autoregulation. Mol. Cell. Biol. 26, 480-488.

Fernandez, H. R., Kavi, H. H., Xie, W., and Birchler, J. A. (2005). Heterochromatin: on the ADAR radar? Curr. Biol. 15, R132-R134.

Flomen, R., and Makoff, A. (2011) Increased RNA editing in EAAT2 pre-mRNA from amyotrophic lateral sclerosis patients: involvement of a cryptic polyadenylation site. Neurosci. Lett. 497, 139-143.

Fu, Y. H., Pizzuti, A., Fenwick, R. G. Jr., King, J., Rajnarayan, S., Dunne,
P. W., etal. (1992). An unstable triplet repeat in a gene related to myotonic muscular dystrophy. Science 255, 1256-1258.

Furuno, M., Pang, K. C., Ninomiya, N. Fukuda, S., Frith, M. C., Bult, C., et al. (2006). Clusters of internally primed transcripts reveal novel long noncoding RNAs. PLoS Genet. 2:e37. doi: 10.1371/journal.pgen.0020037

Gallo, J. M., Jin, P., Thornton, C. A., Lin, H., Robertson, J., D'Souza, I., et al. (2005). The role of RNA and RNA processing in neurodegeneration. $J$. Neurosci. 25, 10372-10375.

Gardiner, K., and Du, Y. (2006). Ato-I editing of the 5HT2C receptor and behaviour. Brief. Funct. Genomic Proteomic 5, 37-42.

Gatchel, J. R., and Zoghbi, H. Y. (2005). Diseases of unstable repeat expansion: mechanisms and common principles. Nat. Rev. Genet. 6, 743-755.

George, C. X., Wagner, M. V., and Samuel, C. E. (2005). Expression of interferon-inducible RNA adenosine deaminase ADAR1 during pathogen infection and mouse embryo development involves tissue-selective promoter utilization and alternative splicing. J. Biol. Chem. 280, 1502015028.

Ghildiyal, M., and Zamore, P. D. (2009). Small silencing RNAs: an expanding universe. Nat. Rev. Genet. 10, 94-108.

Guibert, S., Forne, T., and Weber, M. (2012). Global profiling of DNA methylation erasure in mouse primordial germ cells. Genome Res. 22, 633-641.

Gurevich, I., Tamir, H., Arango, V., Dwork, A. J., Mann, J. J., and Schmauss, C. (2002). Altered editing of serotonin $2 \mathrm{C}$ receptor premRNA in the prefrontal cortex of depressed suicide victims. Neuron 34 , 349-356.

Hackler, E. A., Airey, D. C., Shannon, C. C., Sodhi, M. S., and Sanders-Bush, E. (2006). 5-HT(2C) receptor RNA editing in the amygdala of C57BL/6J, DBA/2J, and BALB/cJ mice. Neurosci. Res. 55, 96-104.

Hagerman, R. J., Ono, M. Y., and Hagerman, P. J. (2005). Recent advances in fragile $\mathrm{X}$ : a model for autism and neurodegeneration. Curr. Opin. Psychiatry 18, 490-496.

Han, J., Kim, D., and Morris, K. V. (2007). Promoter-associated RNA is required for RNA-directed transcriptional gene silencing in human cells. Proc. Natl. Acad. Sci. U.S.A. 104, 12422-12427.

Hansen, K. F., Karelina, K., Sakamoto, K., Wayman, G. A., Impey, S., and Obrietan, K. (2012). miRNA-132: a dynamic regulator of cognitive capacity. Brain Struct. Funct. doi: 10.1007/s00429-0120431-4 [Epub ahead of print].

Haramati, S., Chapnik, E., Sztainberg, Y., Eilam, R., Zwang, R., Gershoni, N., et al. (2010). miRNA malfunction causes spinal motor neuron disease. Proc. Natl. Acad. Sci. U.S.A. 107, 13111-13116.

Harraz, M. M., Dawson, T. M., and Dawson, V. L. (2011). MicroRNAs in Parkinson's disease. J. Chem. Neuroanat. 42, 127-130.

Heale, B. S., Keegan, L. P., Mcgurk, L., Michlewski, G., Brindle, J., Stanton, C. M., et al. (2009). Editing independent effects of ADARs on the miRNA/siRNA pathways. EMBO J. 28, 3145-3156.

Hideyama, T., Yamashita, T., Aizawa, H., Tsuji, S., Kakita, A., Takahashi, H., et al. (2012). Profound downregulation of the RNA editing enzyme ADAR2 in ALS spinal motor neurons. Neurobiol. Dis. 45, 1121-1128.

Holmes, S. E., O’Hearn, E., and Margolis, R. L. (2003). Why is SCA12 different from other SCAs? Cytogenet. Genome Res. 100, 189-197.

Holmes, S. E., O’Hearn, E. E., Mcinnis, M. G., Gorelick-Feldman, D. A., Kleiderlein, J. J., Callahan, C., et al. (1999). Expansion of a novel CAG trinucleotide repeat in the $5^{\prime}$ region of PPP2R2B is associated with SCA12. Nat. Genet. 23, 391-392.

Honda, K., Smith, M. A., Zhu, X., Baus, D., Merrick, W. C., Tartakoff, A. M., et al. (2005). Ribosomal RNA in Alzheimer disease is oxidized by bound redox-active iron. J. Biol. Chem. 280, 20978-20986.

Horsch, M., Seeburg, P. H., Adler, T., Aguilar-Pimentel, J. A., Becker, L., Calzada-Wack, J., etal. (2011). Requirement of the RNA-editing Enzyme ADAR2 for Normal Physiology in Mice. J. Biol. Chem. 286, 18614-18622.

Huang, Y., Liu, N., Wang, J. P., Wang, Y. Q., Yu, X. L., Wang, Z. B., et al. (2012). Regulatory long non-coding RNA and its functions. J. Physiol. Biochem. 68, 611-618.

Ideker, T., and Sharan, R. (2008). Protein networks in disease. Genome Res. 18, 644-652.

Irimia, M., Denuc, A., Ferran, J. L., Pernaute, B., Puelles, L., Roy, S. W., et al. (2012). Evolutionarily conserved Ato-I editing increases protein stability of the alternative splicing factor Nova1. RNA Biol. 9, 12-21.

Iwamoto, K., and Kato, T. (2003). RNA editing of serotonin $2 \mathrm{C}$ receptor in human postmortem brains of major mental disorders. Neurosci. Lett. 346, 169-172. 
Iwamoto, K., Nakatani, N., Bundo, M., Yoshikawa, T., and Kato, T. (2005) Altered RNA editing of serotonin 2C receptor in a rat model of depression. Neurosci. Res. 53, 69-76.

Jacobs, M. M., Fogg, R. L., Emeson, R. B., and Stanwood, G. D. (2009). ADAR1 and ADAR2 expression and editing activity during forebrain development. Dev. Neurosci. $31,223-237$.

Jepson, J. E., and Reenan, R. A. (2010). Unraveling pleiotropic functions of A-to-I RNA editing in Drosophila. Fly (Austin) 4, 154-158.

Jiang, H., Mankodi, A., Swanson, M. S., Moxley, R. T., and Thornton, C. A. (2004). Myotonic dystrophy type 1 is associated with nuclear foci of mutant RNA, sequestration of muscleblind proteins and deregulated alternative splicing in neurons. Hum. Mol. Genet. 13, 3079-3088.

Johnson, R. (2012). Long non-coding RNAs in Huntington's disease neurodegeneration. Neurobiol. Dis. 46, 245-254.

Johnson, R., Richter, N., Jauch, R., Gaughwin, P. M., Zuccato, C., Cattaneo, E., et al. (2010). The Human Accelerated Region 1 noncoding RNA is repressed by REST in Huntington's disease. Physiol. Genomics doi: 10.1152/physiolgenomics.00019.2010 [Epub ahead of print].

Junn, E., and Mouradian, M. M. (2012). MicroRNAs in neurodegenerative diseases and their therapeutic potential. Pharmacol. Ther. 133, 142-150.

Kanduri, C., Whitehead, J., and Mohammad, F. (2009). The long and the short of it: RNA-directed chromatin asymmetry in mammalian $\mathrm{X}$ chromosome inactivation. FEBS Lett. $583,857-864$.

Kapranov, P., Cheng, J., Dike, S., Nix, D. A., Duttagupta, R., Willingham, A. T., et al. (2007). RNA maps reveal new RNA classes and a possible function for pervasive transcription. Science 316, 1484-1488.

Kawahara, Y., Ito, K., Ito, M., Tsuji, S., and Kwak, S. (2005). Novel splice variants of human ADAR2 mRNA: skipping of the exon encoding the dsRNA-binding domains, and multiple C-terminal splice sites. Gene 363 , 193-201.

Kawahara, Y., Sun, H., Ito, K., Hideyama, T., Aoki, M., Sobue, G., et al. (2006). Underediting of GluR2 mRNA, a neuronal death inducing molecular change in sporadic ALS, does not occur in motor neurons in ALS1 or SBMA. Neurosci. Res. 54, 11-14.
Kawahara, Y., Zinshteyn, B., Chendrimada, T. P., Shiekhattar, R., and Nishikura, K. (2007). RNA editing of the microRNA-151 precursor blocks cleavage by the Dicer-TRBP complex. EMBO Rep. 8, 763-769.

Keegan, L. P., Brindle, J., Gallo, A., Leroy, A., Reenan, R. A., and O'Connell M. A. (2005). Tuning of RNA editing by ADAR is required in Drosophila. EMBO J. 24, 2183-2193.

Kennett, G. A., Wood, M. D., Bright, F., Trail, B., Riley, G., Holland, V., et al. (1997). SB 242084, a selective and brain penetrant 5-HT2C receptor antagonist. Neuropharmacology 36, 609-620.

Kiesel, P., Kues, A., Kaup, F. J., Bodemer, W., Gibson, T. J., and Zischler, H. (2012). A comparative analysis to study editing of small noncoding BC200- and Alu transcripts in brain of prion-inoculated rhesus monkeys (M. Mulatta). J. Toxicol. Environ. Health A 75, 391-401.

Kim, D. D., Kim, T. T., Walsh, T., Kobayashi, Y., Matise, T. C., Buyske, S., et al. (2004a). Widespread RNA editing of embedded alu elements in the human transcriptome. Genome Res. 14, 1719-1725.

Kim, J., Krichevsky, A., Grad, Y., Hayes, G. D., Kosik, K. S., Church, G. M., et al. (2004b). Identification of many microRNAs that copurify with polyribosomes in mammalian neurons. Proc. Natl. Acad. Sci. U.S.A. 101, 360-365.

Kishore, S., Khanna, A., Zhang, Z. Hui, J., Balwierz, P. J., Stefan, M. etal. (2010). The snoRNA MBII52 (SNORD 115) is processed into smaller RNAs and regulates alternative splicing. Hum. Mol. Genet. 19, 1153-1164.

Kishore, S., and Stamm, S. (2006). Regulation of alternative splicing by snoRNAs. Cold. Spring Harb. Symp. Quant. Biol. 71, 329-334.

Kiss, A. M., Jady, B. E., Bertrand, E., and Kiss, T. (2004). Human box H/ACA pseudouridylation guide RNA machinery. Mol. Cell. Biol. 24, 5797-5807.

Kiss, A. M., Jady, B. E., Darzacq, X., Verheggen, C., Bertrand, E., and Kiss, T. (2002). A Cajal body-specific pseudouridylation guide RNA is composed of two box H/ACA snoRNA-like domains. Nucleic Acids Res. 30, 4643-4649.

Koob, M. D., Moseley, M. L., Schut, L. J., Benzow, K. A., Bird, T. D., Day, J. W., et al. (1999). An untranslated CTG expansion causes a novel form of spinocerebellar ataxia (SCA8). Nat. Genet. 21, 379-384.
Kubota, T., Miyake, K., and Hirasawa, T. (2012). Epigenetic understanding of gene-environment interactions in psychiatric disorders: a new concept of clinical genetics. Clin. Epigenetics 4,1 .

Kuersten, S., and Goodwin, E. B. (2003). The power of the $3^{\prime}$ UTR: translational control and development. Nat. Rev. Genet. 4, 626-637.

Kwak, S., and Kawahara, Y. (2005). Deficient RNA editing of GluR2 and neuronal death in amyotropic lateral sclerosis. J. Mol. Med. (Berl.) 83, 110-120.

Kwak, S., Nishimoto, Y., and Yamashita, T. (2008). Newly identified ADARmediated A-to-I editing positions as a tool for ALS research. RNA Biol. 5, 193-197.

Lau, P., and de Strooper, B. (2010). Dysregulated microRNAs in neurodegenerative disorders. Semin. Cell Dev. Biol . 21, 768-773.

Lee, J. W., Beebe, K., Nangle, L. A., Jang, J., Longo-Guess, C. M., Cook, S. A., et al. (2006). Editing-defective tRNA synthetase causes protein misfolding and neurodegeneration. Nature 443 , 50-55.

Levanon, E. Y., Eisenberg, E., Yelin, R., Nemzer, S., Hallegger, M., Shemesh, R., et al. (2004). Systematic identification of abundant A-to-I editing sites in the human transcriptome. Nat. Biotechnol. 22, 1001-1005.

Lewis, A., and Reik, W. (2006). How imprinting centres work. Cytogenet. Genome Res. 113, 81-89.

Luciano, D. J., Mirsky, H., Vendetti, N. J., and Maas, S. (2004). RNA editing of a miRNA precursor. RNA 10 , 1174-1177.

Luco, R. F., Allo, M., Schor, I. E., Kornblihtt, A. R., and Misteli, T. (2011). Epigenetics in alternative pre-mRNA splicing. Cell 144, 16-26.

Luco, R. F., and Misteli, T. (2011). More than a splicing code: integrating the role of RNA, chromatin and noncoding RNA in alternative splicing regulation. Curr. Opin. Genet. Dev. 21, 366-372.

Macbeth, M. R., Schubert, H. L., Vandemark, A. P., Lingam, A. T., Hill, C. P., and Bass, B. L. (2005). Inositol hexakisphosphate is bound in the ADAR2 core and required for RNA editing. Science 309, 1534-1539.

Mahadevan, M., Tsilfidis, C., Sabourin, L., Shutler, G., Amemiya, C., Jansen, G., etal. (1992). Myotonic dystrophy mutation: an unstable CTG repeat in the $3^{\prime}$ untranslated region of the gene. Science 255, 12531255.

Martin, J. R., Bos, M., Jenck, F., Moreau, J., Mutel, V., Sleight, A. J., et al.
(1998). 5-HT2C receptor agonists: pharmacological characteristics and therapeutic potential. J. Pharmacol. Exp. Ther. 286, 913-924.

Matsuura, T., Yamagata, T., Burgess, D. L., Rasmussen, A., Grewal, R. P., Watase, K., et al. (2000). Large expansion of the ATTCT pentanucleotide repeat in spinocerebellar ataxia type 10. Nat. Genet. 26, 191-194.

Mattick, J. S. (2003). Challenging the dogma: the hidden layer of nonprotein-coding RNAs in complex organisms. Bioessays 25, 930-939.

Mattick, J. S., and Gagen, M. J. (2001). The evolution of controlled multitasked gene networks: the role of introns and other noncoding RNAs in the development of complex organisms. Mol. Biol. Evol. 18, 1611-1630.

Mattick, J. S., and Makunin, I. V. (2005). Small regulatory RNAs in mammals. Hum. Mol. Genet. 14, R121-R132.

Mattick, J. S., and Makunin, I. V. (2006). Non-coding RNA. Hum. Mol. Genet. 15, R17-R29.

Mattick, J. S., and Mehler, M. F. (2008). RNA editing, DNA recoding and the evolution of human cognition. Trends Neurosci. 31, 227-233.

Matzke, M., Kanno, T., Huettel, B., Daxinger, L., and Matzke, A. J. (2007). Targets of RNA-directed DNA methylation. Curr. Opin. Plant Biol. 10, 512-519.

Mehler, M. F. (2008). Epigenetic principles and mechanisms underlying nervous system functions in health and disease. Prog. Neurobiol. 86, 305-341.

Mehler, M. F., and Mattick, J. S. (2007). Noncoding RNAs and RNA editing in brain development, functional diversification, and neurological disease. Physiol. Rev. 87, 799-823.

Meier, U. T. (2005). The many facets of H/ACA ribonucleoproteins. Chromosoma $114,1-14$.

Melcher, T., Maas, S., Herb, A., Sprengel, R., Higuchi, M., and Seeburg, P. H. (1996). RED2, a brain-specific member of the RNA-specific adenosine deaminase family. J. Biol. Chem. 271, 31795-31798.

Mercer, T. R., Qureshi, I. A., Gokhan, S., Dinger, M. E., Li, G., Mattick, J. S., et al. (2010). Long noncoding RNAs in neuronal-glial fate specification and oligodendrocyte lineage maturation. BMC Neurosci. 11:14. doi: 10.1186/1471-2202-11-14

Mette, M. F., Aufsatz, W., Van Der Winden, J., Matzke, M. A., and Matzke, A. J. (2000). Transcriptional silencing and promoter methylation triggered by double-stranded RNA. EMBO J. 19, 5194-5201. 
Migicovsky, Z., and Kovalchuk, I. (2011). Epigenetic memory in mammals. Front. Genet. 2:28. doi: 10.3389/fgene.2011.00028

Miyake, K., Hirasawa, T., Koide, T., and Kubota, T. (2012). Epigenetics in autism and other neurodevelopmental diseases. Adv. Exp. Med. Biol. 724, 91-98.

Morabito, M. V., Abbas, A. I., Hood, J. L., Kesterson, R. A., Jacobs, M. M., Kump, D. S., et al. (2010). Mice with altered serotonin $2 \mathrm{C}$ receptor RNA editing display characteristics of Prader-Willi syndrome. Neurobiol. Dis. 39, 169-180.

Morse, D. P., Aruscavage, P. J., and Bass, B. L. (2002). RNA hairpins in noncoding regions of human brain and Caenorhabditis elegans mRNA are edited by adenosine deaminases that act on RNA. Proc. Natl. Acad. Sci. U.S.A. 99, 7906-7911.

Mutsuddi, M., Marshall, C. M., Benzow, K. A., Koob, M. D., and Rebay, I. (2004). The spinocerebellar ataxia 8 noncoding RNA causes neurodegeneration and associates with staufen in Drosophila. Curr. Biol. 14, 302-308.

Neeman, Y., Levanon, E. Y., Jantsch, M. F., and Eisenberg, E. (2006). RNA editing level in the mouse is determined by the genomic repeat repertoire. RNA 12, 1802-1809.

Nemes, J. P., Benzow, K. A., Moseley, M. L., Ranum, L. P., and Koob, M. D. (2000). The SCA8 transcript is an antisense RNA to a brain-specific transcript encoding a novel actinbinding protein (KLHL1). Hum. Mol. Genet. 9, 1543-1551.

Nishikura, K. (2006). Editor meets silencer: crosstalk between RNA editing and RNA interference. Nat. Rev. Mol. Cell Biol. 7, 919-931.

Niswender, C. M., Copeland, S. C., Herrick-Davis, K., Emeson, R. B., and Sanders-Bush, E. (1999). RNA editing of the human serotonin 5-hydroxytryptamine $2 \mathrm{C}$ receptor silences constitutive activity. J. Biol. Chem. 274, 9472-9478.

O'Neill, M. J. (2005). The influence of non-coding RNAs on allele-specific gene expression in mammals. Hum. Mol. Genet. 14, R113-R120.

Ohman, M. (2007). A-to-I editing challenger or ally to the microRNA process. Biochimie 89, 1171-1176.

Pal-Bhadra, M., Bhadra, U., and Birchler, J. A. (2002). RNAi related mechanisms affect both transcriptional and posttranscriptional transgene silencing in Drosophila. Mol. Cell. 9, 315-327.

Palladino, M. J., Keegan, L. P., O'Connell, M. A., and Reenan, R.
A. (2000). A-to-I pre-mRNA editing in Drosophila is primarily involved in adult nervous system function and integrity. Cell 102, 437-449.

Pang, K. C., Frith, M. C., and Mattick, J. S. (2006). Rapid evolution of noncoding RNAs: lack of conservation does not mean lack of function. Trends Genet. 22, 1-5.

Paro, S., Li, X., O'Connell, M. A., and Keegan, L. P. (2012). Regulation and functions of ADAR in Drosophila. Curr. Top. Microbiol. Immunol 353, 221-236.

Pascual, M., Vicente, M., Monferrer, L., and Artero, R. (2006) The Muscleblind family of proteins: an emerging class of regulators of developmentally programmed alternative splicing. Differentiation 74 , 65-80.

Paul, M. S., and Bass, B. L. (1998). Inosine exists in mRNA at tissue-specific levels and is most abundant in brain mRNA. EMBO J. 17, 1120-1127.

Paupard, M. C., O'Connell, M. A., Gerber, A. P., and Zukin, R. S. (2000). Patterns of developmental expression of the RNA editing enzyme rADAR2. Neuroscience 95, 869-879.

Poulsen, H., Jorgensen, R., Heding, A., Nielsen, F. C., Bonven, B., and Egebjerg, J. (2006). Dimerization of ADAR2 is mediated by the doublestranded RNA binding domain. RNA 12, 1350-1360.

Prasanth, K. V., Prasanth, S. G., Xuan, Z., Hearn, S., Freier, S. M., Bennett, C. F. et al. (2005). Regulating gene expression through RNA nuclear retention. Cell 123, 249-263.

Qureshi, I. A., and Mehler, M. F. (2011). Non-coding RNA networks underlying cognitive disorders across the lifespan. Trends Mol. Med. 17, 337-346.

Qureshi, I. A., and Mehler, M. F. (2012). Emerging roles of non-coding RNAs in brain evolution, development, plasticity and disease. Nat. Rev. Neurosci. 13, 528-541.

Ranum, L. P., Rasmussen, P. F., Benzow, K. A., Koob, M. D., and Day, J. W. (1998). Genetic mapping of a second myotonic dystrophy locus. Nat. Genet. 19, 196-198.

Reenan, R. A. (2001). The RNA world meets behavior: A $\rightarrow$ I pre-mRNA editing in animals. Trends Genet. 17, 53-56.

Rogelj, B., and Giese, K. P. (2004) Expression and function of brain specific small RNAs. Rev. Neurosci. 15, 185-198.

Rogelj, B., Hartmann, C. E., Yeo, C. H., Hunt, S. P., and Giese, K. P. (2003). Contextual fear conditioning regulates the expression of brain-specific small nucleolar RNAs in hippocampus. Eur. J. Neurosci. 18, 3089-3096.

Rueter, S. M., Dawson, T. R., and Emeson, R. B. (1999). Regulation of alternative splicing by RNA editing. Nature 399, 75-80.

Saito, Y., and Saito, H. (2012). MicroRNAs in cancers and neurodegenerative disorders. Front. Genet. 3:194. doi: 10.3389/fgene.2012.00194

Salta, E., and De Strooper, B. (2012). Non-coding RNAs with essential roles in neurodegenerative disorders. Lancet Neurol. 11, 189-200.

Sansam, C. L., Wells, K. S., and Emeson, R. B. (2003). Modulation of RNA editing by functional nucleolar sequestration of ADAR2. Proc. Natl. Acad. Sci. U.S.A. 100, 14018-14023.

Satoh, J. (2012). Molecular network of microRNA targets in Alzheimer's disease brains. Exp. Neurol. 235, 436-446.

Scadden, A. D., and Smith, C. W. (2001). RNAi is antagonized by $\mathrm{A} \rightarrow \mathrm{I}$ hyperediting. EMBO Rep. 2, 1107-1111.

Schellekens, H., Finger, B. C., Dinan, T. G., and Cryan, J. F. (2012). Ghrelin signalling and obesity: at the interface of stress, mood and food reward. Pharmacol Ther.135, 316-326.

Sie, C. P., and Kuchka, M. (2011). RNA editing adds flavor to complexity. Biochemistry (Mosc) 76, 869-881.

Simpson, L., and Emeson, R. B. (1996). RNA editing. Annu. Rev. Neurosci. 19, 27-52.

Singh, M., Kesterson, R. A., Jacobs, M. M., Joers, J. M., Gore, J. C., and Emeson, R. B. (2007). Hyperphagia-mediated obesity in transgenic mice misexpressing the RNA-editing enzyme ADAR2. J. Biol. Chem. 282, 22448-22459.

Singh, M., Singh, M. M., Na, E., Agassandian, K., Zimmerman, M. B., and Johnson, A. K. (2011). Altered ADAR 2 equilibrium and $5 \mathrm{HT}(2 \mathrm{C}) \mathrm{R}$ editing in the prefrontal cortex of ADAR 2 transgenic mice. Genes Brain Behav $10,637-647$.

Singh, M., Zimmerman, M. B., Beltz, T. G., and Johnson, A. K. (2009). Affect-related behaviors in mice misexpressing the RNA editing enzyme ADAR2. Physiol. Behav. 97, 446-454.

Sleutels, F., Barlow, D. P., and Lyle, R. (2000). The uniqueness of the imprinting mechanism. Curr. Opin. Genet. Dev 10, 229-233.

Sodhi, M. S., Airey, D. C., Lambert, W., Burnet, P. W., Harrison, P. J., and Sanders-Bush, E. (2005). A rapid new assay to detect RNA editing reveals antipsychotic-induced changes in serotonin-2C transcripts. Mol. Pharmacol. 68, 711-719.
Sodhi, M. S., Burnet, P. W., Makoff, A. J., Kerwin, R. W., and Harrison, P. J. (2001). RNA editing of the 5-HT(2C) receptor is reduced in schizophrenia. Mol. Psychiatry 6, 373-379.

Song, X., Wang, X., Arai, S., and Kurokawa, R. (2012). Promoterassociated noncoding RNA from the CCND1 promoter. Methods Mol. Biol. 809, 609-622.

Sonntag, K. C. (2010). MicroRNAs and deregulated gene expression networks in neurodegeneration. Brain Res. 1338, 48-57.

Tonkin, L. A., Saccomanno, L., Morse, D. P., Brodigan, T., Krause, M., and Bass, B. L. (2002). RNA editing by ADARs is important for normal behavior in Caenorhabditis elegans. EMBO J. 21, 6025-6035.

Tran, V. G., Court, F., Duputie, A., Antoine, E., Aptel, N., Milligan, L., et al. (2012). H19 antisense RNA can up-regulate igf 2 transcription by activation of a novel promoter in mouse myoblasts. PLoS ONE 7:e37923. doi:10.1371/journal.pone.0037923

Valente, L., and Nishikura, K. (2005). ADAR gene family and A-to-I RNA editing: diverse roles in posttranscriptional gene regulation. Prog. $\mathrm{Nu}$ cleic Acid Res. Mol. Biol. 79, 299-338.

Valente, L., and Nishikura, K. (2007). RNA binding-independent dimerization of adenosine deaminases acting on RNA and dominant negative effects of nonfunctional subunits on dimer functions. J. Biol. Chem. 282, 16054-16061.

Van Esch, H. (2006). The Fragile X premutation: new insights and clinical consequences. Eur. J. Med. Genet. 49, $1-8$.

Vesely, C., Tauber, S., Sedlazeck, F. J., Von Haeseler, A., and Jantsch, M. F. (2012). Adenosine deaminases that act on RNA induce reproducible changes in abundance and sequence of embryonic miRNAs. Genome Res. 22, 1468-1476.

Vitali, P., Basyuk, E., Le Meur, E., Bertrand, E., Muscatelli, F., Cavaille, J., et al. (2005). ADAR2-mediated editing of RNA substrates in the nucleolus is inhibited by $\mathrm{C} / \mathrm{D}$ small nucleolar RNAs. J. Cell Biol. 169, 745-753.

Wang, G., Van Der Walt, J. M., Mayhew, G., Li, Y. J., Zuchner, S., Scott, W. K., et al. (2008). Variation in the miRNA433 binding site of FGF20 confers risk for Parkinson disease by overexpression of alpha-synuclein. Am. J. Hum. Genet. 82, 283-289.

Wang, Q., Miyakoda, M., Yang, W., Khillan, J., Stachura, D. L., Weiss, M. J., et al. (2004a). Stressinduced apoptosis associated with null mutation of ADAR1 RNA editing 
deaminase gene. J. Biol. Chem. 279, 4952-4961.

Wang, Y., Joh, K., Masuko, S., Yatsuki, H., Soejima, H., Nabetani, A., et al. (2004b). The mouse Murrl gene is imprinted in the adult brain, presumably due to transcriptional interference by the antisense-oriented U2af1rs1 gene. Mol. Cell. Biol. 24, 270-279.

Wang, Y., Li, S., Chen, L., You, G., Bao, Z., Yan, W., et al. (2012). Glioblastoma with an oligodendroglioma component: distinct clinical behavior, genetic alterations, and outcome. Neuro oncol. 14, 518-525.

Waterston, R. H., Lindblad-Toh, K., Birney, E., Rogers, J., Abril, J. F., Agarwal, P., et al. (2002). Initial sequencing and comparative analysis of the mouse genome. Nature 420, 520-562.
Wright, A., and Vissel, B. (2012). The essential role of AMPA receptor GluR2 subunit RNA editing in the normal and diseased brain. Front. Mol. Neurosci. 5:34. doi 10.3389/fnmol.2012.00034

Yang, J. H., Nie, Y., Zhao, Q., Su, Y., Pypaert, M., Su, H., etal. (2003). Intracellular localization of differentially regulated RNA-specific adenosine deaminase isoforms in inflammation. J. Biol. Chem. 278, 45833-45842.

Yang, P. K., and Kuroda, M. I. (2007). Noncoding RNAs and intranuclear positioning in monoallelic gene expression. Cell 128, 777-786.

Yang, W., Chendrimada, T. P., Wang, Q., Higuchi, M., Seeburg, P.
H., Shiekhattar, R., etal. (2006). Modulation of microRNA processing and expression through RNA editing by ADAR deaminases. Nat. Struct. Mol. Biol. 13, 13-21.

Zhou, J., Wang, Q., Chen, L. L., and Carmichael, G. G. (2008). On the mechanism of induction of heterochromatin by the RNAbinding protein vigilin. RNA 14, 1773-1781.

Conflict of Interest Statement: The author declares that the research was conducted in the absence of any commercial or financial relationships that could be construed as a potential conflict of interest.
Received: 25 July 2012; accepted: 28 December 2012; published online: 22 January 2013.

Citation: Singh M (2013) Dysregulated A to I RNA editing and non-coding RNAs in neurodegeneration. Front. Gene. 3:326. doi: 10.3389/fgene.2012.00326

This article was submitted to Frontiers in Non-Coding RNA, a specialty of Frontiers in Genetics.

Copyright $\odot 2013$ Singh. This is an openaccess article distributed under the terms of the Creative Commons Attribution License, which permits use, distribution and reproduction in other forums, provided the original authors and source are credited and subject to any copyright notices concerning any third-party graphics etc. 